\title{
PELAKSANAAN PROMOSI KESEHATAN RUMAH SAKIT DI RSU HAJI SURABAYA
}

\author{
IMPLEMENTATION OF HOSPITAL HEALTH PROMOTION IN RSU HAJI \\ SURABAYA
}

\author{
Adi Larasanti \\ Departemen Promosi Kesehatan dan Ilmu Perilaku, \\ Fakultas Kesehatan Masyarakat, Universitas Airlangga, Surabaya. \\ E-mail: adilarasanti82@gmail.com
}

\begin{abstract}
Health Promotion is an effort to empower communities to maintain, improve and protect their own health and environment. Hospital Health Promotion (PKRS) targeting patients, community, hospital and the surrounding environment is a program implemented at RSU Haji Surabaya to obtain accreditation. The purpose of PKRS at Rumah Sakit Umum Haji Surabaya is to develop patient and family understanding of the illness suffered as well as the things that his family needs to do, in assisting healing and preventing reinfection by the same disease. If implemented properly, PKRS can contribute greatly to improving the quality and image of health services in Indonesia, especially RSU Haji Surabaya. This research is a qualitative analysis research with descriptive approach to analyze health promotion in Rumah Sakit Umum Haji Surabaya by conducting in depth interview with research respondents. The research results of Analysis Hospital Health Promotion of Rumah Sakit Umum Haji Surabaya Based on the Peraturan Menteri Kesehatan Republik Indonesia Nomor 004 Tahun 2012, the result that the use of electronic media has not been delivered, advocacy activities tend not to run and the partnership aspect has not reached the large scale private sector. In this research, it can be concluded that the implementation of hospital health promotion in Rumah Sakit Umum Haji Surabaya has not been running maximally so that the participation of the Board of Directors, the community and all employees of Rumah Sakit Umum Haji Surabaya are needed. If the health promotion program runs well then it will affect the level of people satisfaction.
\end{abstract}

Keywords: Hospital Health Promotion, RSU Haji Surabaya

\begin{abstract}
Abstrak: Promosi Kesehatan adalah suatu cara yang dilakukan pada masyarakat agar dapat melakukan pencegahan terhadap penyakit sehingga meningkatkan derajat kesehatan diri dan lingkungan. Promosi Kesehatan Rumah Sakit (PKRS) dengan pasien, masyarakat, rumah sakit dan lingkungannya merupakan sasaran untuk program yang diterapkan di RSU Haji Surabaya dalam memperoleh akreditasi. Tujuan PKRS di Rumah Sakit Umum Haji Surabaya adalah membantu pasien dan keluarganya agar lebih mengetahui tentang penyakit yang sedang dialami, serta membantu proses pengembangan dan pencegahan agar tidak kembali terkena penyakit yang sama di masa yang akan datang. Apabila PKRS diterapkan dengan baik maka hal tersebut dapat memberikan manfaat yang besar bagi peningkatan mutu dan citra pelayanan kesehatan di Indonesia terutama RSU Haji Surabaya. Penelitian ini termasuk penelitian analisis kualitatif menggunakan pendekatan deskriptif untuk menganalisis promosi kesehatan yang ada di Rumah Sakit umum Haji Surabaya dengan melakukan wawancara yang mendalam dengan responden penelitian. Hasil penelitian Analisis Promosi Kesehatan Rumah Sakit Umum Haji Surabaya Berdasarkan Peraturan Menteri Kesehatan Republik Indonesia Nomor 004 Tahun 2012 diperoleh hasil bahwa penggunaan media elektronik belum tersampaikan, kegiatan advokasi cenderung tidak berjalan dan aspek kemitraan belum menjangkau pihak swasta berskala besar. Dalam penelitian ini dapat disimpulkan bahwa pelaksanaan promosi kesehatan rumah sakit di RSU Haji Surabaya belum berjalan maksimal sehingga perlu peran serta dari Direksi, masyarakat dan seluruh karyawan RSU Haji Surabaya. Apabila program promosi kesehatan rumah sakit dapat berjalan dengan baik maka akan meningkatkan nilai tingkat kepuasan masyarakat terhadap RSU Haji Surabaya.
\end{abstract}

Kata kunci: Promosi Kesehatan Rumah Sakit (PKRS), RSU Haji Surabaya 


\section{PENDAHULUAN}

Mutu layanan kesehatan dapat dilihat dari ketersediaan layanan kesehatan yang peduli pada kebutuhan dan harapan pasien. Nilai pasien dapat menjadi tolak ukur terhadap penyediaan pelayanan kesehatan. Hal tersebut menjadi salah satu syarat yang harus dapat terpenuhi. Untuk mewujudkan derajat kesehatan masyarakat yang menyeluruh, peningkatan kesehatan di Indonesia ditujukan untuk dapat melaksanakan visi "Indonesia Sehat" yang merupakan harapan bagi bangsa Indonesia di masa yang akan datang agar dapat hidup dalam lingkungan yang sehat. Dengan demikian penduduk memiliki perilaku hidup bersih dan sehat yang memungkinkannya untuk mampu menjangkau pelayanan kesehatan yang bermutu, adil serta merata dalam mencapai kesehatan yang optimal (Fitriani, 2011).

Masyarakat memiliki hak untuk mendapatkan pelayanan kesehatan yang optimal sesuai dengan kebutuhannya. Kebutuhan akan pelayanan kesehatan dasar maupun rujukan haruslah dilihat tanpa membedakan status sosial. UndangUndang Dasar Negara Republik Indonesia Tahun 1945 dalam Pasal 28H ayat (1) menjelaskan tentang hak bagi setiap orang untuk dapat hidup dengan sejahtera secara lahir dan batin. Memiliki tempat tinggal di lingkungan hidup yang baik, sejahtera, sehat dan dapat memperoleh pelayanan kesehatan. Undang-Undang Nomor 36 Pasal 3 Tahun 2009 tentang Kesehatan menjelaskan tentang pembangunan kesehatan untuk setiap orang dengan tujuan agar dapat menumbuhkan rasa sadar, mau, dan mampu untuk dapat hidup sehat demi terwujudnya derajat kesehatan masyarakat yang paling tinggi. Apabila dilihat dari segi sosial dan ekonomisnya maka dapat menjadi sebuah investasi yang bernilai bagi pertumbuhan sumber daya manusia yang produktif (Muninjaya, 2004).

Pemerintah dan sarana kesehatan mempunyai kewajiban untuk dapat mengendalikan dan menyempurnakan pelayanan yang disediakan kepada masyarakat. Undang-Undang Nomor 44 tahun 2009 yang menjelaskan tentang terwujudnya derajat kesehatan yang tertinggi untuk masyarakat, dilakukan berbagai macam upaya kesehatan secara terpadu dan menyeluruh bagi kesehatan perseorangan dan masyarakat. Upaya kesehatan dilakukan melalui berbagai bentuk kegiatan secara terpadu, menyeluruh, dan berkesinambungan dengan menggunakan pendekatan promotif, preventif, kuratif dan rehabilitatif (Fitriani, 2011).

Menurut Ketetapan Majelis Permusyawaratan Rakyat Indonesia (TAP MPR RI) Nomor X Tahun 1998 mengenai berbagai pokok reformasi pembangunan yang mengamanatkan diperlukan adanya pembaharuan dalam seluruh bidang termasuk dalam bidang kesehatan melalui reformasi total kebijakan pembangunan (Notoatmodjo, 2003). Rumah sakit sebagai fasilitas pelayanan publik dalam bidang kesehatan sebagai tempat penyedia dan pemberi layanan kesehatan. Termasuk dalam berbagai macam masalah kesehatan. Rumah sakit juga sebagai salah satu institusi yang menyelenggarakan pemberian jasa kesehatan yang kompleks, padat pakar dan modal. Kompleksitas yang muncul dapat disebabkan oleh layanan rumah sakit yang terkait dalam berbagai fungsi pelayanan, pendidikan dan penelitian, serta meliputi berbagai macam tingkatan disiplin keahlian (Suroso, 2011).

Menurut Maulana (2009), rumah sakit menjadi bagian dalam sistem kesehatan yang memiliki peranan untuk mendukung ketersediaan pelayanan kesehatan dasar melalui adanya fasilitas rujukan dan mekanisme pemberian bantuan. Menurut Organisasi Kesehatan Dunia atau World Health Organization (WHO) tahun 2004, "Rumah Sakit harus terintegrasi dalam sebuah sistem kesehatan dimana pun keberadaannya. Fungsinya agar rumah sakit dapat menjadi pusat sumber daya untuk peningkatan kesehatan masyarakat di wilayahnya (Hartono, 2010). UndangUndang Nomor 44 tahun 2009 menyebutkan bahwa upaya kesehatan dilaksanakan dalam berbagai bentuk kegiatan menggunakan pendekatan promotif, preventif, kuratif, dan rehabilitatif secara terpadu, menyeluruh, dan berkesinambungan. Namun pada UndangUndang RI Nomor 44 tahun 2009 tersebut belum menunjukkan bahwa peran rumah 
sakit juga meliputi promotif dan preventif, maka di tahun 2012 dikeluarkanlah Peraturan Menteri Kesehatan (Permenkes) No. 004 tahun 2012 yang di dalamnya meliputi promotif dan preventif. Kegiatan pelayanan promotif dan preventif diberikan melalui layanan promosi kesehatan dalam bentuk upaya peningkatan kemampuan masyarakat yang diperoleh melalui pembelajaran dari, oleh, untuk dan bersama masyarakat untuk menolong dirinya sendiri. Mengembangkan kegiatan yang bersumber daya masyarakat sesuai dengan sosial budaya dan mendapat dukungan kebijakan publik yang memiliki wawasan kesehatan (Maulana, 2009).

Promosi kesehatan memerlukan sumber daya manusia yang faham akan fungsi dan pentingnya promosi kesehatan karena petugas yang bekerja atau ditempatkan di bidang Promosi Kesehatan Rumah Sakit (PKRS) yang belum memahami dengan tugasnya akan sulit mencapai tujuan peningkatan derajat kesehatan masyarakat. Persepsi atau pemahaman seseorang dapat dipengaruhi oleh pengetahuan, sikap, tindakan serta adanya tuntutan aturan atau kebijakan yang menopang suatu kegiatan tertentu. Promosi kesehatan merupakan pengembangan konsep pendidikan kesehatan pada masa lampau.

Promosi kesehatan merupakan upaya yang dilakukan oleh individu, masyarakat dan pihak yang berwenang agar dapat meningkatkan kemampuannya untuk dapat mengatur berbagai faktor yang dapat memberikan pengaruh terhadap peningkatan derajat kesehatan. Promosi kesehatan tidak hanya sebuah bentuk kesadaran oleh masyarakat atau memberikan peningkatan terhadap pengetahuan masyarakat mengenai bidang kesehatan, akan tetapi meliputi berbagai usaha untuk memberikan fasilitas terhadap perubahan perilaku. Menurut Notoatmodjo (2005) pada tahun 1986 di Ottawa, Canada, telah diselenggarakan Konferensi Promosi Kesehatan Internasional yang pertama kali dengan hasil berupa Piagam Ottawa (Ottawa Charter). Piagam tersebut menjadi panduan bagi promosi kesehatan secara umum, termasuk promosi kesehatan rumah sakit. Berdasarkan Piagam Ottawa tersebut, dirumuskanlah strategi dasar promosi kesehatan yaitu empowerment, social support and advocacy yang di dalam Bahasa Indonesia diartikan sebagai pemberdayaan masyarakat, bina suasana dan advokasi.

Permenkes No. 004 tahun 2012 tentang petunjuk teknis promosi kesehatan rumah sakit telah menjelaskan bahwa Promosi Kesehatan Rumah Sakit atau sering disingkat PKRS mempunyai persamaan dan perbedaan dalam hal kegiatan pemasaran (marketing) dan kehumasan (public relation) yang dilaksanakan di rumah sakit. Beberapa rumah sakit ada yang menggabung ketiga kegiatan tersebut menjadi satu organisasi, tetapi ada pula yang lebih memilih untuk memisahkannya. Persamaannya kegiatan tersebut yang paling utama yaitu terletak pada sasaran (target group).

Promosi kesehatan menjadi bagian yang tidak dapat dipisahkan dari program pelayanan kesehatan yang terdapat di rumah sakit. Rumah sakit merupakan instansi pelayanan kesehatan yang memiliki hubungan secara langsung dengan pasien sehingga rumah sakit harus memberikan pelayanan kesehatan yang aman, bermutu, tidak diskriminatif dan efektif sebagai hal utama. Hal tersebut merupakan program dari kegiatan PKRS. PKRS juga menjadi salah satu syarat dalam penilaian akreditasi 2012 sehingga dalam pelaksanaan kegiatannya diatur dan dipantau agar tujuan PKRS terwujud seperti yang diamanatkan oleh Permenkes Nomor 004 tahun 2012 tentang Pelaksanaan Kegiatan Promosi Kesehatan.

RSU Haji Surabaya menjadi salah satu dari sekian banyak rumah sakit di Indonesia yang menerapkan promosi kesehatan sebagai bagian yang penting dalam meningkatkan mutu pelayanan rumah sakit. Sejak berdiri hingga sekarang, RSU Haji Surabaya telah mendapatkan penghargaan dan prestasi antara lain: gelar The Most Recommended Hospital tahun 2011, lalu lulus ISO 9001:2008 pada Desember 2011, kemudian mendapatkan akreditasi rumah sakit tahun 2015 (RSU Haji Surabaya, 2015). RSU Haji Surabaya telah melakukan kegiatan promosi kesehatan sejak tahun 2014, pembentukan tim PKRS RSU Haji Surabaya telah disahkan melalui keputusan Direktur Rumah Sakit Umum Haji Surabaya No. 445/038/304/2014 (profil RSU Haji 
Surabaya). Berdasarkan survei awal yang telah dilakukan melalui wawancara dengan ketua PKRS di RSU Haji bahwa pelaksanaan kegiatannya masih belum bisa optimal dan belum berjalan dengan baik karena tidak adanya instalasi khusus yang menangani PKRS dan masih berada di bawah naungan Kepala Sub. Bag. Hukum dan Pemasaran.

Peran tim Promosi Kesehatan RSU Haji Surabaya diperlukan demi menunjang maupun meningkatkan mutu, kinerja dan manajemen rumah sakit. Tujuan pembentukan PKRS RSU Haji Surabaya adalah untuk meningkatkan upaya promosi kesehatan RSU Haji Surabaya demi terciptanya masyarakat yang dapat menerapkan perilaku hidup sehat serta mampu dalam mencegah dan mengatasi masalah kesehatan yang dihadapi, sesuai dengan Permenkes No. 004 tahun 2012. PKRS RSU Haji Surabaya diharapkan dapat mengantarkan seseorang baik itu pasien, keluarga pasien, masyarakat, maupun pihak rumah sakit sendiri, mampu dalam meningkatkan derajat kesehatan.

Berdasarkan latar belakang diatas maka perlu dilakukan analisis pelaksanaan PKRS di RSU Haji Surabaya termasuk strategi pelaksanaannya berkaitan dengan pentingnya promosi kesehatan bagi RSU Haji Surabaya untuk meningkatkan mutu pelayanan yang mengutamakan hak pasien, keluarga, karyawan maupun masyarakat seperti yang terlampir dalam Permenkes Nomor 004 tahun 2012.

\section{METODE}

Penelitian ini dilakukan di RSU Haji Surabaya dengan berfokus pada berbagai kegiatan tim Promosi Kesehatan Rumah Sakit (PKRS). Metode yang diterapkan oleh penulis dalam penelitian ini adalah dengan menggunakan metode analisis kualitatif deskriptif.

Metode kualitatif adalah suatu analisis berupa informasi, uraian dalam bentuk prosa. Dikaitkan dengan data lainnya untuk memperoleh kejelasan suatu kebenaran atau sebaliknya, sehingga didapatkan sebuah gambaran baru atau memperkuat gambaran yang sudah ada atau sebaliknya serta di dukung dengan teori-teori tertentu.

Penelitian tentang pelaksanaan PKRS ini dilakukan selama 5 bulan yaitu bulan April-Agustus 2016 di RSU Haji Surabaya.

Sumber informasi dalam penelitian ini adalah data primer berupa wawancara kepada narasumber atau informan dari tim PKRS, dan data sekunder berupa arsip dan dokumen yang ada dari rumah sakit. Untuk mendapatkan informasi yang lebih akurat maka dalam penelitian ini digunakan teknik triangulasi dengan tujuan menjaring sebanyak mungkin informasi dari berbagai macam sumber. Informan atau narasumber dalam penelitian ini adalah: 1.Direktur Rumah Sakit Umum Haji Surabaya, 2. Ketua PKRS RSU Haji Surabaya dan 3. Kepala Sub. Bag. HukMas RSU Haji Surabaya

Dalam melakukan proses pengumpulan data digunakan beberapa metode sebagai berikut: 1. Data primer didapatkan dari observasi berbagai kegiatan yang dilakukan oleh tim PKRS berkaitan dengan penyelenggaraan dan wawancara kepada pihak terkait berupa pertanyaan-pertanyaan yang berkaitan dengan judul penelitian, 2. Data sekunder dengan dokumenter (studi kepustakaan).

Teknik analisis data yang digunakan mencakup transkrip hasil wawancara, reduksi data, analisis, interpretasi data dan triangulasi untuk kemudian dilakukan penarikan kesimpulan. Teknik analisis data yang digunakan: 1) Reduksi Data yang merupakan penyederhanaan berbagai jawaban yang berasal dari pertanyaan yang diberikan pada pihak tertentu dalam teknik pengumpulan data. Hasil akan difokuskan pada hal yang terkait dengan judul penelitian. Kemudian diambil kesimpulan berupa uraian singkat sesuai dengan hasil penyajian. Kesimpulan disusun dalam bentuk pernyataan singkat dan mudah dipahami yang mengacu dari tujuan penelitian, 2) Triangulasi adalah teknik pemeriksaan keabsahan data yang memanfaatkan hal lain untuk membandingkan hasil wawancara terhadap objek penelitian (Moleong, 2006). Tujuan umum dilakukannya triangulasi yaitu untuk dapat meningkatkan kekuatan 
teoritis, metodologis, maupun interpretatif dari sebuah riset.

\section{HASIL PENELITIAN}

RSU Haji Surabaya telah menerapkan program PKRS sejak beberapa tahun yang lalu. Meskipun di beberapa instalasi sempat terjadi kevakuman pelaksanaan PKRS, namun RSU Haji Surabaya tetap berbenah. Sebagaimana hasil wawancara dengan Ketua tim PKRS sebagai berikut:

"Ya PKRS ini sempat vakum beberapa tahun, cuman kita berusaha menggalakkan lagi terutama ada kegiatan yang sebenernya sudah rutin ya, rutin contohnya dari Gizi itu dia sudah rutin setiap minggu beberapa kali kemudian dari PPI kita PKRS juga masuk ke situ. Memang ada yang programnya itu istilahnya jangka pendek dan jangka panjang. Nah yang jangka pendek sepertinya sudah lumayan berjalan"

Upaya RSU Haji Surabaya dalam pelaksanaan promosi kesehatan telah mengalami perkembangan yang sangat baik, meski begitu dalam kaitannya dengan tujuan PKRS yang ada dalam petunjuk teknis yang tertuang dalam Permenkes No. 004 tahun 2012, masih belum semuanya tercapai. Sejak RSU Haji berdiri hingga sekarang belum semua kegiatan berjalan lancar untuk kegiatan PKRS. Meskipun demikian RSU Haji Surabaya telah mendapatkan penghargaan dan prestasi antara lain: gelar The Most Recommended Hospital dari Hermawan Kertajaya tahun 2011, lalu lulus ISO 9001:2008 dengan 16 pelayanan pada Desember 2011, kemudian pada tahun 2011 pendapatan akreditasi rumah sakit dari Komisi Akreditasi Rumah Sakit (KARS). Pada tahun 2015 RSU Haji lulus akreditasi pelayanan paripurna (RSU Haji Surabaya, 2015).

Peran tim Promosi Kesehatan Rumah Sakit Umum Haji Surabaya sangatlah penting demi menunjang peningkatan mutu, kinerja dan manajemen rumah sakit. Pada tahun 2014, pembentukan tim PKRS RSU Haji Surabaya telah disahkan melalui keputusan Direktur Rumah Sakit Umum Haji Surabaya No. 445/038/304/2014 dan dalam pelaksanaan tugasnya dilakukan upaya pemusatan kegiatan PKRS yakni di Subbag Hukmas dan Pemasaran. Dimana dalam pelaksanaan kegiatannya dilaksanakan melalui koordinasi dengan seluruh unit. Hal ini karena tidak adanya instalasi khusus yang menaungi PKRS sehingga kegiatan yang dilakukan oleh tim PKRS RSU Haji Surabaya belum dapat dikatakan baik.

Dalam upaya melaksanakan kegiatan PKRS secara terpadu dan menyeluruh, maka perlu dilakukan upaya pemusatan kegiatan PKRS di Subbag Hukmas dan Pemasaran yang dilaksanakan oleh Tim PKRS RSU Haji Surabaya. Pemusatan kegiatan PKRS dilaksanakan melalui koordinasi dengan seluruh unit yang telah melaksanakan kegiatan PKRS diunitnya masing-masing. Setiap unit diminta untuk menyerahkan materi edukasi dan jadwal pelaksanaan edukasi untuk selanjutnya dikoordinir dan difasilitasi oleh Tim PKRS.

Pelaksanaan Promosi Kesehatan Rumah Sakit berdasarkan Permenkes Nomor 004 Tahun 2012 Tentang Petunjuk Teknis Promosi Kesehatan Rumah Sakit, secara struktur organisasi PKRS berdiri sendiri dan tidak berada di bawah Hukmas dikarenakan terdapat perbedaan kegiatan antara PKRS dan Hukmas.

Tim PKRS RSU Haji Surabaya dibentuk sejak 6 Januari 2014, dan diperbarui kembali untuk tim PKRS pada tahun 2017 dengan jumlah tenaga tim kurang lebih 33 orang pada tahun 2016 melalui SK terbaru menjadi 64 orang dengan tim edukatornya, dengan pendidikan minimal yaitu sarjana dalam Bidang Kesehatan dan sebelumnya sudah pernah mengikuti lokalatif mengenai PKRS. Selain itu, keseluruhan tim PKRS, masing-masing memiliki tugas pokok dan fungsi utama. Perencanaan kegiatan PKRS RSU Haji Surabaya, menggunakan sistem bottom up, yaitu setiap unit bekerja dengan menyusun rencana untuk kemudian didiskusikan dengan semua panitia dan diusulkan kepada Direksi.

Terdapat beberapa strategi yang dicanangkan oleh RSU Haji Surabaya. Menggunakan rencana yang disusun secara strategis, maka diharapkan untuk membuat suatu tujuan dan target program pelayanan kesehatan yang specific, measurable, 
acceptable, realistic, time bound (SMART) yang sesuai dengan visi dan misi RSU Haji Surabaya. Salah satu rencana strategis program kerja PKRS adalah didukung oleh metode komunikasi dan adanya media yang tepat, serta sumber daya yang memadai berdasarkan jumlah tenaga atau SDM, sarana dan anggaran dana.

Adapun kegiatan pokok yang diselenggarakan oleh Tim PKRS antara lain: 1) Pemusatan kegiatan PKRS di subbag hukmas dan pemasaran yaitu dalam upaya melaksanakan kegiatan PKRS secara menyeluruh dan terpadu, maka perlu upaya pemusatan kegiatan di subbag humas dan pemasaran yang dilaksanakan oleh tim PKRS RSU Haji Surabaya. Pemusatan ini dilaksanakan melalui koordinasi dengan seluruh unit yang telah melaksanakan kegiatan PKRS di unitnya masing-masing. Kemudian setiap unit diminta untuk menyerahkan materi edukasi dan jadwal pelaksanaan edukasi untuk selanjutnya dikoordinir dan difasilitasi oleh Tim PKRS, 2) Pendidikan kesehatan. menurut Notoadmojo (2005), promosi kesehatan merupakan pendidikan kesehatan (health education) dikarenakan bahwa pendidikan mengenai kesehatan mempunyai prinsip yang ditujukan bagi masyarakat agar memiliki perilaku yang sesuai nilai kesehatan. Pendidikan kesehatan dibagi menjadi 2 kegiatan, yaitu: pendidikan kesehatan kelompok dan individu. Pendidikan kesehatan kelompok yang diselenggarakan di RSU Haji meliputi penyuluhan, seminar atau talk show. Sedangkan pendidikan kesehatan individu dilaksanakan di poli rawat jalan dan rawat inap RSU Haji oleh perawat terhadap pasien yang masuk dalam kategori 10 penyakit terbanyak. Namun dalam pelaksanaannya masih mengalami kesulitan dikarenakan keterbatasan tenaga, 3) Kegiatan pendidikan kesehatan di luar gedung, meliputi: Pendidikan kesehatan di luar gedung dilaksanakan melalui kerja sama dengan Dinas Kesehatan Kota Surabaya yaitu dengan melaksanakan kegiatan penyuluhan di puskesmas, penyuluhan kesehatan di SKPD Pemerintah Provinsi Jawa Timur, Talkshow kesehatan kepada masyarakat yang dilaksanakan bersamaan dengan kegiatan pameran, Talkshow kesehatan melalui media televisi, keberadaan tulisan "Kawasan Tanpa Rokok" di halaman parkir RSU Haji Surabaya, pembuatan media edukasi kesehatan (leaflet, poster, videotron, website dan spanduk) untuk mendukung kegiatan PKRS, senam bagi penderita diabetes, pendidikan dan pelatihan dan rapat rutin dilaksanakan pada minggu ke-dua dan ke-empat setiap bulan sebagai evaluasi terhadap kegiatan PKRS.

Pelaksanaan promosi kesehatan berdasarkan Permenkes Nomor 004 Tahun 2012 Tentang Petunjuk Teknis Promosi Kesehatan Rumah Sakit, secara umum dikategorikan menjadi 2, yaitu di dalam dan di luar gedung. Berdasarkan analisis hasil penelitian pelaksanaan Promosi Kesehatan Rumah Sakit di RSU Haji Surabaya telah sesuai dengan Permenkes Nomor 004 Tahun 2012 tentang Petunjuk Teknis Promosi Kesehatan Rumah Sakit.

Perencanaan SDM merupakan proses yang berjalan secara sistematis untuk memberikan perkiraan terhadap permintaan dan penyediaan Sumber Daya Manusia pada masa mendatang. Dapat dilakukan perkiraan terhadap jumlah dan jenis tenaga kerja yang dibutuhkan dalam periode waktu tertentu untuk mendukung Sumber Daya Manusia pada proses rencana rekrutmen, seleksi, pendidikan dan pelatihan.

Dari penelitian yang dilakukan didapatkan hasil penelitian dengan kesimpulan bahwa perencanaan SDM untuk menjalankan promosi kesehatan RSU Haji Surabaya membentuk struktur dalam pembagian tugas dan rincian tugas secara tertulis. SDM dipilih berdasarkan pendidikan khusus yang dibutuhkan rumah sakit. Sebagaimana disampaikan oleh Kasubbag Hukmas:

"Jadi kalo disini ada tenaga lulusan SKM yang bertugas sebagai tenaga dan kenaikan kepangkatannya melalui promotor kesehatan"

Sumber daya manusia yang mendapatkan tanggung jawab untuk melakukan upaya promosi kesehatan rumah sakit telah melakukan tugasnya dan melaksanakan tanggung jawab yang 
telah diberikan. Masih terdapat beberapa kekurangan mengenai kemampuan khusus, terutama pada petugas instalasi PKRS.

Hal lain yang menjadi perhatian rumah sakit terkait sumber daya manusia sebagaimana hasil wawancara dengan direktur yaitu terbatasnya jumlah petugas PKRS:

"Secara khusus sih ada ya tapi mungkin jumlahnya yang tidak memadai untuk membuat program PKRS secara total gitu baik dari sisi design pemikiran trus tata cara pelaksanaan"

Untuk upaya perbaikan sampai saat ini pihak RSU Haji Surabaya belum memberi perhatian secara khusus berkaitan dengan ketersediaan SDM yang menangani khusus PKRS, hal ini diketahui dari hasil kutipan wawancara dengan Ketua PKRS sebagai berikut:

"Belum ada tenaga khusus untuk petugas PKRS"

Senada dengan hal tersebut, Direktur RSU Haji Surabaya menyampaikan:

"Menurut saya sih sangat kecil. Jauh dari memadai, kalau kita pengen PKRS itu ideal ... Itu paling nggak kan PKRS tu 4 atau 5 orang"

Dari hasil penelitian yang berkaitan dengan evaluasi diketahui bahwa kualitas SDM secara keseluruhan sudah cukup baik. Akan tetapi masih terkendala dengan jumlah petugas yang fokus pada PKRS itu sendiri.

Ketersediaan dana untuk pelaksanaan PKRS, RSU Haji Surabaya telah mempunyai dana khusus. Untuk pengadaan dana tersebut, terlebih dahulu dilakukan pengajuan proposal ke pihak direksi. Dana tersebut akan dibuat anggarannya, hal ini dilakukan supaya jelas dana tersebut dalam penggunaannya. Sebagaimana disampaikan oleh salah satu dokter RSU Haji Surabaya:

"Ada, program itu disini ada tim panitia yaitu PKMRS yang diketuai oleh $d r$. Nining, kemudian untuk anggarannya berada di Hukmas"

Dari hasil di atas dapat dinilai bahwa aspek anggaran PKRS mendapatkan dukungan penuh dari direksi sebagai top manajemen. Hal ini juga diketahui dari kutipan wawancara sebagai berikut:
"Sangat mendukung, mau tidak mau harus dianggar. Terbukti dengan adanya anggaran yang ada di hukmas, jadi kita harus mendukung promosi kesehatan ini karena kita juga harus menjaga kesehatan. Tidak hanya untuk berobat tapi untuk tidak sakit"

Adapun masalah anggaran PKRS ini, akan dipertenggungjawabkan kembali ke jajaran direksi yaitu Wadir Umum dan Keuangan.

Berdasarkan penelitian yang telah dilakukan diketahui bahwa saat ini pihak RSU Haji Surabaya telah memiliki fasilitas yang cukup memadai untuk pelaksanaan PKRS. Fasilitas tersebut berupa media cetak maupun media elektronik yang masingmasing penempatannya dapat dijangkau oleh seluruh elemen rumah sakit. Media cetak seperti, banner, leaflet, brosur, spanduk dan juga melalui media elektronik seperti televisi, komputer, LCD dan lain sebagainya secara umum sudah tersedia. Meskipun demikian, tidak semua sudut rumah sakit dimanfaatkan, hal ini terlihat dari pemanfaatan ruang tunggu belum bisa terlaksana, karena tidak terdapat petugas yang memanfaatkan waktu tunggu pasien untuk pelaksanaan promosi kesehatan. Pasien hanya menunggu nomor antrean dan pada saat itu juga petugas tidak ambil bagian dalam pelayanan kesehatan untuk promosi kesehatan. Televisi yang terdapat di ruang tunggu dipergunakan sebagai sarana hiburan bagi pasien disela waktu tunggu. Tidak banyak terdapat info-info kesehatan yang terdapat di ruang tunggu tersebut.

Untuk melengkapi sarana promosi rumah sakit, dilengkapi juga dengan sarana videotron. Dengan videotron ini diharapkan semua informasi berkaitan dengan promosi bahkan aspek bisnis lainnya dapat terakomodasi. Sebagaimana hasil wawancara dengan Ketua tim PKRS sebagai berikut:

"Itu semua kita informasikan melalui videotron ya kurang lebih bentuknya hampirsama dengan company profile tapi contentnya lebih ke bisnis inti kita pelayanan kesehatan"

Berdasarkan hasil penelitian dan wawancara juga diketahui bahwa terdapat 
aspek KIE (Konsultasi Individual) khusus bagi pasien yang membutuhkan penanganan khusus. Sebagaimana wawancara dengan Ketua PKRS sebagai berikut:

"Rawat inap tidak terlalu kecuali pada pasien-pasien yang gawat tu baru, di pasien-pasien KIE itu ya"

Secara umum peluang kegiatan PKRS di RSU Haji Surabaya yang terletak di luar gedung, di beberapa tempat belum dilaksanakan secara optimal. Di tempat parkir RSU Haji Surabaya sudah terdapat beberapa promosi kesehatan yang bersifat umum seperti imbauan berperilaku hidup bersih dan sehat, larangan merokok, larangan menyalahgunakan narkoba, bahaya NAPZA dan lain sebagainya. Di dinding rumah sakit juga dimanfaatkan untuk promosi kesehatan dengan menggunakan poster yang ditata dengan rapi berisikan pesan-pesan umum tentang kesehatan serta Perilaku Hidup Bersih dan Sehat (PHBS). Di kantin rumah sakit juga didapati poster berisikan pesan tentang makanan sehat, gizi seimbang, keluarga sadar gizi dan PHBS. Sementara itu di tempat ibadah belum didapati poster PKRS.

Meskipun secara umum kegiatan PKRS dapat dikatakan berjalan cukup baik, namun masih terdapat beberapa kendala. Salah satunya yaitu masalah sumber daya manusia, dimana belum ada petugas khusus yang menangani PKRS. Berikut ini wawancara dengan Direktur:

"Menurut saya sih sangat kecil. Jauh dari memadai, kalau kita pengen PKRS itu ideal. Jadi memang dari dulu jaman saya di mana itu ya begitu, selalu benturannya kepada anggaran, jumlah SDM yang menggalang seperti itu. Orangnya sangat terbatas. Itu paling nggak kan PKRS tu 4 atau 5 orang"

Berdasarkan wawancara di atas dapat disimpulkan bahwa selain dari segi anggaran yang dinilai kurang memadai, ketersediaan SDM juga menjadi hambatan bagi kelangsungan kegiatan PKRS.

Pemberdayaan diberlakukan untuk setiap pasien. Petugas rumah sakit yang memberikan pelayanan kepada pasien harus meluangkan waktu untuk dapat menjawab seluruh pertanyaan yang diajukan oleh pasien mengenai penyakit yang sedang diderita dan mengenai berbagai obat yang akan dikonsumsi oleh pasien. Apabila hal tersebut belum memungkinkan untuk dapat diterapkan, maka perlu adanya penyediaan ruangan khusus untuk pasien rawat jalan yang membutuhkan konsultasi atau informasi. Ruangan konsultasi disediakan di bagian poliklinik dan dilayani oleh dokter atau perawat yang kompeten di bidangnya. Di dalam praktiknya, dengan banyaknya jumlah pasien dan ruangan yang masih terbatas, seringkali pemberdayaan dilakukan secara berkelompok dengan pasien yang menunggu giliran.

Menurut Notoatmojo (2005), tujuan pemberdayaan adalah memberikan bantuan kepada klien untuk mendapatkan kemampuan dalam mengambil tindakan dan membuat keputusan yang berhubungan dengan diri mereka. Pemberdayaan dilakukan dengan cara meningkatkan kemampuan serta kepercayaan diri untuk dapat menggunakan kemampuannya.

Pihak yang memiliki pengaruh besar terhadap pasien adalah orang terdekat atau keluarga yang mengantarkan pasien ke rumah sakit. Mereka dalam keadaan sehat dan tidak mengalami sakit, sehingga memiliki kemungkinan untuk memperoleh informasi yang berasal dari media komunikasi yang tersedia. Oleh karena itu di setiap poliklinik, khususnya di ruang tunggu, terdapat berbagai poster, selebaran (leaflet), dan media televisi serta $\mathrm{VCD} /$ DVD player yang dibuat khusus untuk dapat menayangkan berbagai informasi mengenai penyakit yang berlangsung secara terus menerus.

Di dalam praktiknya meskipun RSU Haji Surabaya sudah melakukan berbagai upaya dalam pemberian informasi baik melalui poster, leaflet maupun media elektronik, namun penyampaian informasi tersebut terkadang kurang mengena pada pasien maupun keluarga pasien. Seringkali pemberian informasi yang dilakukan melalui media elektronik terabaikan bahkan tergolong tergesa-gesa dalam menyampaikan. Hal tersebut dikarenakan ruangan yang terbatas sehingga dalam penyampaian sering terhambat oleh pasien atau keluarga pasien yang berlalu 
lalang mengurus administrasi. Selain itu, kurangnya kesadaran masyarakat mengenai pentingnya memberikan informasi kepada orang lain.

Berikut kutipan wawancara dengan Direktur RSU Haji Surabaya:

"Ya sebetulnya bisa juga melalui sarana videotron itu kita memberikan informasi ke pengunjung jenis layanannya apa aja, keunggulan kita apa saja, apa yang bisa kita kerjakan di $R S$, dari sisi pengobatan penunjang, operasi, dan lain-lain. Itu semua kita informasikan melalui videotron ya kurang lebih bentuknya hampir sama dengan company profile tapi contentnya lebih ke bisnis inti kita pelayanan kesehatan. Tetapi memang penggunaan videotron itu kurang maksimal sebagai media yang digunakan dim PKRS"

Hasil wawancara menunjukkan bahwa upaya dalam melaksanakan Promosi Kesehatan Rumah Sakit di RSU Haji Surabaya telah sesuai dengan tujuan dari pemberdayaan kesehatan di masyarakat. Dengan menggunakan media videotron diharapkan masyarakat mampu menyerap pembelajaran yang disampaikan sehingga menjadikan dirinya mampu mengambil keputusan atas dirinya yang didasari oleh pengetahuan yang telah bertambah.

Berdasarkan Permenkes Nomor 004 Tahun 2012 Tentang Petunjuk Teknis Promosi Kesehatan Rumah Sakit, Keberhasilan dari pemberdayaan akan menjadi lebih cepat apabila mendapat dukungan dengan adanya berbagai kegiatan atau dengan adanya lingkungan di sekitar yang kondusif. Kegiatan yang menciptakan suasana atau lingkungan yang kondusif itu disebut dengan bina suasana. Pelaksanaan bina suasana dalam kegiatan Promosi Kesehatan Rumah Sakit di RSU Haji Surabaya sudah sesuai dengan Permenkes Nomor 004 Tahun 2012 Tentang Petunjuk Teknis Promosi Kesehatan Rumah Sakit. Ujung tombak dari keberhasilan pemberdayaan manusia harus mendapat dukungan dari berbagai upaya dalam masyarakat (Adisasmito, 2010).

Dari hasil pengamatan di lapangan belum ada buku pedoman atau acuan khusus mengenai advokasi. Selama ini perawat hanya mengacu pada SPO (Standart Prosedure Operational) tindakan asuhan keperawatan dan berdasarkan pengalaman mereka dalam memberikan pelayanan kesehatan. Sebagian yang lain terkendala adanya perawat baru yang masih dalam proses pembelajaran. Menurut salah satu kepala instalasi, perawat-perawat di sana masih kurang dalam sisi advokasi dan perlu pembelajaran lagi. Perawat dirasakan sudah memberikan informasi dan berusaha memenuhi hak-hak pasien namun dirasakan masih kurang karena perawat terkadang menjelaskan hanya pada saat ditanya oleh pasien.

Pelaksanaan strategi advokasi dalam Promosi Kesehatan Rumah Sakit di RSU Haji juga didukung dengan pimpinan RSU Haji Surabaya menerbitkan peraturan mengenai kawasan tanpa rokok di lingkungan RSU Haji Surabaya. Terbitnya peraturan mengenai kawasan tanpa asap rokok di kawasan RSU Haji Surabaya diharapkan akan mendukung kegiatan Promosi Kesehatan Rumah Sakit yang sesuai dengan Permenkes Nomor 004 Tahun 2012 Tentang Petunjuk Teknis Promosi Kesehatan Rumah Sakit.

Tim PKRS RSU Haji Surabaya kurang melakukan pendekatan kepada top management RSU Haji Surabaya dalam upaya mendukung kegiatan PKRS di RSU Haji Surabaya. Tim PKRS RSU Haji Surabaya tidak menempuh tahapan-tahapan advokasi berdasarkan Permenkes Nomor 004 Tahun 2012 Tentang Petunjuk Teknis Promosi Kesehatan Rumah Sakit yang menyatakan bahwa advokasi yang dijelaskan adalah sebagai berikut: Mengerti masalah yang akan diajukan, Memiliki keinginan untuk turut serta berperan dalam masalah yang akan diajukan, mempertimbangkan beberapa pilihan lainnya yang memiliki kemungkinan akan berperan, menyetujui satu pilihan yang mungkin berperan dan Mengutarakan tahapan dari tindak lanjut.

Menurut Notoatmodjo (2005), advokasi merupakan usaha yang dilakukan untuk dapat memengaruhi kebijakan publik melalui berbagai macam komunikasi persuasif. Disimpulkan bahwa advokasi merupakan upaya dari proses dalam mendapatkan sebuah komitmen dengan memanfaatkan 
berbagai informasi yang tepat dan akurat yang dilakukan secara persuasif.

Kebijakan sebagai bagian-bagian dari promosi kesehatan, karena promoter kesehatan yang bekerja dapat sebagai pengantar dari suatu kebijakan yang nantinya akan berpengaruh dalam pelaksanaan kegiatan promosi kesehatan, Ewles (1994). Penerapan suatu kebijakan juga dilakukan oleh pimpinan RSU Haji Surabaya sebagai upaya dalam memperkuat promosi kesehatan di rumah sakit yang dipimpinnya.

Strategi kemitraan dalam kegiatan Promosi Kesehatan Rumah Sakit di RSU Haji juga menjalin kemitraan dengan Dinas Kesehatan Kota Surabaya melalui pembinaan Puskesmas. Rumah Sakit Umum Haji Surabaya juga menjalin MOU dengan pelanggan RSU Haji yang bertujuan memberikan penjelasan dan kemudahan kepada pasien RSU Haji Surabaya. Menurut Permenkes Nomor 004 Tahun 2012 Tentang Petunjuk Teknis Promosi Kesehatan Rumah Sakit, kemitraan diperluas antara petugas rumah sakit dengan sasarannya, yaitu pasien, klien atau pihak lain dan juga dalam pelaksanaannya juga dilakukan pemberdayaan bina suasana dan advokasi.

Kemitraan dapat membuat efektivitas kegiatan PKRS menjadi meningkat. Petugas di rumah sakit dapat melakukan kerja sama dengan berbagai pihak terkait misalnya Lembaga Swadaya Masyarakat (LSM), kelompok profesi, pemuka agama dan lainnya. Strategi kemitraan dalam pelaksanaan Promosi Kesehatan Rumah Sakit di RSU Haji Surabaya masih belum maksimal tetapi prinsip dasar kemitraan sudah sesuai dengan Permenkes Nomor 004 Tahun 2012 Tentang Petunjuk Teknis Promosi Kesehatan Rumah Sakit yaitu prinsip kesetaraan, prinsip keterbukaan dan prinsip saling menguntungkan.

Menurut Notoatmodjo (2005), dalam mengembangkan kemitraan di bidang kesehatan terdapat tiga unsur pokok institusi yang harus terlibat didalamnya, yaitu unsur pemerintahan, dunia usaha atau unsur swasta dan unsur organisasi non pemerintahan atau lembaga swadaya masyarakat, organisasi masa dan organisasi profesi.

Pelaksanaan Promosi Kesehatan Rumah Sakit (PKRS) di RSU Haji
Surabaya, dengan strategi pendukung menggunakan media berupa TV/LCD, VCD/DVD player, Amplifier dan Wireless Microphone, Computer dan laptop, Pointer, Public Address System (PSA)/Megaphone, Plypchart besar/kecil, Cassette recorder/ Player, kamera foto.

Sumber Daya Manusia (SDM) dengan tenaga khusus yang memiliki kualifikasi dan kompetensi sebagai tim PKRS RSU Haji Surabaya. Pendukung pelaksanaan berdasarkan Permenkes Nomor 004 Tahun 2012 Tentang Petunjuk Teknis Promosi Kesehatan Rumah Sakit, sudah sesuai dengan pelaksanaan pendukung PKRS di RSU Haji Surabaya.

Media promosi atau penyuluhan kesehatan yang ada di rumah sakit menjadi alat yang dapat membantu untuk dapat menyampaikan berbagai pesan dan informasi mengenai kesehatan pasien sekaligus pada orang yang mengunjungi rumah sakit. Media promosi yang digunakan antara lain: leaflet, selebaran, poster, spanduk, media elektronik dan video kaset.

\section{KESIMPULAN}

Berdasarkan tujuan khusus penelitian, hasil penelitian dan pembahasan mengenai promosi kesehatan rumah sakit di RSU Haji Surabaya, dapat diperoleh kesimpulan sebagai berikut: PKRS tidak hanya menjadi urusan bagi tim yang bertugas di unit PKRS saja, melainkan menjadi tanggung jawab dari direksi rumah sakit. PKRS menjadi tugas bagi hampir semua jajaran struktur rumah sakit. Untuk mewujudkan program PKRS, maka perlu adanya strategi baik itu metode, media dan sumber daya yang memadai sehingga akan terlaksana program tersebut dengan baik. Disamping itu, perlu adanya pengembangan dalam mewujudkan rumah sakit yang menerapkan hidup sehat serta agar rumah sakit menjadi pelayanan yang lebih baik. RSU Haji Surabaya belum maksimal dalam merealisasikan bentuk promosi kesehatan sesuai dengan Permenkes Nomor 4 Tahun 2012. Kegiatan pemberdayaan yang dilakukan oleh tim PKRS RSU Haji Surabaya dengan menggunakan videotron masih kurang mendapatkan perhatian dari masyarakat, 
sehingga kegiatan promosi kesehatan tersebut masih belum memberikan dampak yang positif. Media promosi kesehatan tidak dijadikan sebagai media pendidikan namun hanya sebagai wacana yang terkadang diperlukan dan cenderung diabaikan. Banyaknya jumlah pasien dan ruangan yang masih terbatas menyebabkan pemberdayaan PKRS seringkali dilakukan secara berkelompok dengan pasien yang menunggu giliran. Pada aspek bina suasana yang tertera dalam Permenkes RI Nomor 004 Tahun 2012, penyampaian informasi kesehatan di RSU Haji Surabaya terkadang kurang mengena pada pasien maupun keluarga pasien. Pemberian informasi melalui media elektronik masih sering terabaikan karena sarana dan prasarana yang sangat terbatas. Pada aspek advokasi, belum ada buku pedoman atau acuan khusus mengenai advokasi. Selama ini perawat hanya mengacu pada SPO tindakan keperawatan saja. Sebagian lainnya terkendala masalah perawat baru yang masih dalam proses pembelajaran. Pada aspek kemitraan, RSU Haji Surabaya masih kurang optimal karena kegiatan kemitraan belum dapat menjangkau pihak-pihak swasta dalam skala besar.

Adapun saran berdasarkan kesimpulan di atas yaitu: PKRS diharapkan dapat secara aktif lebih melibatkan seluruh tim PKRS rumah sakit, jajaran direksi dan seluruh karyawan rumah sakit, Memaksimalkan fungsi videotron sebagai alat promosi kesehatan, Membentuk divisi atau unit instalasi PKRS yang independen, dengan ruangan khusus serta melengkapi sarana dan prasarana dengan dipimpin oleh bagian PKRS itu sendiri, Meningkatkan advokasi sekaligus kemitraan secara eksternal melalui kerja sama dengan pihak di luar rumah sakit. Disamping itu secara internal, perlu disusun pedoman atau acuan khusus mengenai advokasi untuk memudahkan kegiatan PKRS.

\section{DAFTAR PUSTAKA}

Adisasmito, W. 2010. Sistem Kesehatan. Jakarta: PT. Raja Grafindo Persada.
Ewles, L. 1994. Promosi Kesehatan. Yogyakarta: Gadjah Mada University Press.

Fitriani, S. 2011. Promosi Kesehatan. Yogyakarta: Graha Ilmu.

Hartono, B. 2010. Promosi Kesehatan di Puskesmas dan Rumah Sakit. Jakarta: Rineka Cipta.

Keputusan Menteri Kesehatan Republik Indonesia Nomor 44 Tahun 2009 Tentang Rumah Sakit. Jakarta: Kemenkes.

Notoatmodjo, S. 2003. Pendidikan dan Perilaku Kesehatan. Jakarta: Rineka Cipta.

Notoatmodjo, S. 2005. Promosi Kesehatan: Teori dan Aplikasi. Jakarta: PT. Asdi Mahasatya.

Maulana, H. D. J. 2009. Promosi Kesehatan. Jakarta: EGC.

Moleong, L. 2006. Metodologi Penelitian Kualitatif. Bandung: PT. Remaja Rosdakarya.

Muninjaya, A.A. 2004. Manajemen Kesehatan. Edisi Kedua. Denpasar: EGC.

Peraturan Menteri Kesehatan Republik Indonesia Nomor 004 Tahun 2012 Tentang Petunjuk Teknis Promosi Kesehatan Rumah Sakit. Jakarta: Kemenkes.

Rumah Sakit Umum Haji Surabaya. 2015. Profil RSU Haji Surabaya. Surabaya: RSU Haji.

Rumah Sakit Umum Haji Surabaya. 2015. Laporan Akhir Jasa Konsultasi IKM Semester II Tahun 2015. Surabaya: CV. Sari Rejeki.

Suroso, J. 2011. Indeks Kepuasan Pasien Suatu Rumah Sakit Swasta. Purwokerto: Universitas Muhammadiyah.

Undang-Undang Dasar Republik Indonesia Tahun 1945 Pasal 28H Ayat 1 Tentang Hak Asasi Manusia. Jakarta: Republik Indonesia.

Undang-Undang Republik Indonesia Nomor 36 Tahun 2009 Pasal 3 Tentang Kesehatan. Jakarta: Republik Indonesia.

World Health Organization Europe. 2004. Implementing HP in the Hospital. Barcelona: WHO. 